\title{
THREE DIMENSIONAL STABILITY OF A RECTILINEAR PERIODIC SOLUTION OF THE THREE-BODY PROBLEM, FOR ALL VALUES OF THE MASSES*
}

\section{HÉNoN}

Observatoire de Nice

\section{RESUMEN}

Consideramos la solución rectilínea, periódica, en donde el cuerpo central choca alternativamente con cada uno de los otros dos cuerpos. Se encuentra que esta solución existe para todos los valores de las tres masas. Se calcula su estabilidad con respecto a perturbaciones tri-dimensionales. Se delimitan los dominios de estabilidad e inestabilidad en un diagrama triangular de masas. Se han encontrado grandes dominios de estabilidad. Esto refucrza la conclusion de que sistemas triples pueden tener un movimiento de tipo "interplay".

\section{ABSTRACI}

We consider a rectilinear periodic solution in which the central body collides alternately with cach of the two other bodies. This solution is found to exist for all values of the three masses. Its stability with respect to three-dimensional perturbations is computed. Domains of stability and instability are delimited in a triangular mass diagram. Large domains of stability are found. This reinforces the conclusion that triple stars may have an "interplay" type of motion.

\section{DISCUSSION}

Evans: I have been greatly educated by these contributions and have been trying to think of ways in which actual systems where spectroscopists are pretty thoroughly tied to a hierarchical concept could be brought to a comparison with the theoretical values.

Abt: Do you know of any observed systems that are members of these families?

Henon: No, I have not looked into this. In fact, one of my motives for coming to this " meeting was to ask the observers whether there are any real systems which could possibly have this kind of motion.

Szebehely: Concerning Dr. Evans' remark, I doubt if the values of $k_{1}$ and $k_{2}$ may be used to describe classical systems, such as Psi Sagittarii.

* To be published in Celestial Mechanics. 